\title{
Vegetation Assessment of Inland Wetland of Central Gujarat ( Pariej Irrigation Reservoirs )
}

\author{
Jaivin Patel, Dr. Rupesh Maurya, Dr. Hitesh Solanki, Dr. Bharat Maitreya \\ Department of Botany, Bioinformatics and Climate Change Impacts Management, University School of Sciences, \\ Gujarat University, Navrangpura, Ahmedabad, Gujarat, India
}

\section{Article Info}

Volume 8, Issue 2

Page Number : 316-325

\section{Publication Issue}

March-April-2021

\section{Article History}

Accepted : 01 April 2021

Published : 07 April 2021

\section{ABSTRACT}

Wetlands are one of the most productive and fertile ecosystems on earth. Those wetlands which are located in the transitional zone between permanently aquatic and terrestrial (upland) ecosystems have properties common to land and water both. Gujarat has a variety coastal and inland wetland systems. The inland wetlands include floodplains, freshwater ponds and lakes, rivers, irrigation reservoirs, marshes and waterlogged areas while the coastal wetlands include salt marshes and salt-pans, creeks, mudflats, estuaries, mangrove swamps and coral reefs. Many of these wetlands have potential to get designation of international significance due to their high diversity/population and/or other criteria. Pariej is one of the eight wetlands in Gujarat that has been declared by the Central Government as wetland of national importance. The purpose of the present study is to observe the flora of the pariej wetland and to determine the changes by each season. In a wetland ecosystem these biotic factors are mostly dependent on the season and hydrology. Thus wetland being an integrated system is affected by the changes in the physical as well as chemical parameters of hydrosphere at the catchment scale.

Keywords : Wetlands, productive, ecosystems, aquatic, terrestrial ecosystems, floodplains, freshwater ponds, lakes, rivers, irrigation reservoirs, marshes and waterlogged areas, diversity, biotic factors, hydrology, hydrosphere.

\section{INTRODUCTION}

Wetlands are eco-transitional regions which inhabit a transitional position between dry land and open water (Tatu et. al., 2007). The penetration of wetland never exceeds six meters as defined in the text of convention report of wetlands which are globally important particularly as Water birds habitat known as the Ramsar site. Wetlands are extremely valuable pools of biodiversity and genetic resources, but unmaintainable development is intimidating the biowealth and even initiating species extinction (Burlakova et al, 2009). Wetlands are supportive to a varied range of flora and fauna and inhabit many ecological, climatic and biological roles. Wetlands provides food, shelter and breeding platforms for 
aquatic birds and animals(Turner et. al., 2000). It has a variety of aquatic habitats such as a long Arabian seacoast, rivers, streams, ponds, puddles, lakes, backwater creeks etc., which support characteristic types of vegetation of their own (Callaway et. al., 2007). Pariej is one of the eight wetlands in Gujarat that has been declared by the Central Government as wetland of national importance. It offers a variety of habitats -from the ponds and marshes, to patches of open grasslands and scrub and its proximity of the Gulf of Khambhat as given its wealth of birdlife.

\section{MATERIALS AND METHODS}

\section{Study Area}

Prioritized wetland site from Gujarat. One of the eight wetlands of National Importance identified in Gujarat state by the Ministry of Environment and Forests, Govt. of India. The wetland well known as 'Mahi- Pariejyojna' that stores and supply water to Saurashtra region. This is also an Important Bird Area (IBA) Site of India. Also, a proposed Ramsar Site by SACON (Source: SACON's Atlas for Wetland Conservation). Commercial fishing is practiced.

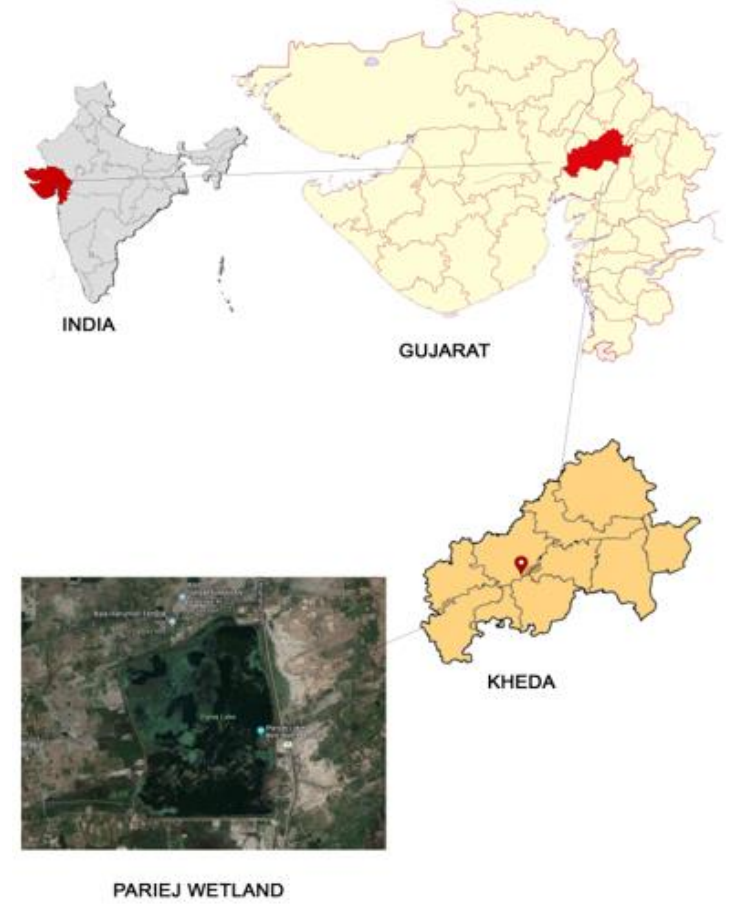

Figure 1 : Satellite image of Pariej Wetland (Source: Google Map)
Location: Pariej Irrigation Reservoir is located in Limbasi taluka at $22^{\circ} 33^{\prime} 00^{\prime \prime} \mathrm{N}$ latitudes and $72^{\circ} 38^{\prime} 00^{\prime \prime}$ $E$ longitudes. It is situated at the distance of just $7 \mathrm{~km}$ north of Tarapur on Tarapur-Kheda State highway. The big lake of Pariej is approximately $2.5 \mathrm{kms}$. in area with depth varying between $4 \mathrm{ft}$ to $10 \mathrm{ft}$.

\section{Field Survey}

The field survey was started with reconnaissance survey of Pariej Wetlands located at Khambhat District of Gujarat state, India. Further, data collection was carried out in each of the season i.e., Summer, Monsoon and Winter. Types of vegetations like Submerged vegetation, Rooted Plants with Floating Leaves, Unrooted Submerged Plant, Freefloating Plants, Emergent vegetation have been covered during study. Belt- transects methods was employed for fulfilment of the objectives.

\section{Belt-Transect}

Belt- Transect method for wetlands ringed with vegetation around large central deep water, a better strategy might be establishing a baseline around the perimeter of the wetland running transect toward the Centre. A length of the transect was $100 \mathrm{~m}$. On each transect, quadrates were laid down at regular distance (i.e.,10m). Quadrates size was fixed as per habit of

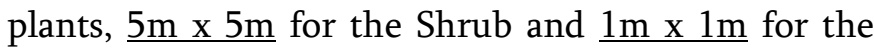
herbs. Each species occurring in the first three quadrate was counted for determination of species density, frequency, abundance, percentage composition and remaining quadrate only Percent cover and frequency percentage was taken because these aquatic species which could not be counted as individual number. Longitude and Latitude were also recorded for each transect \& quadrates by using GPS (Global Positioning System).

\section{Quantitative Data Analysis}

Enumeration of vegetation was carried out using quadrates method. The quantitative assessment was 
carried out for all species. Various measurable attributes i.e., density, frequency, abundance, percentage composition, species richness and evenness were used for the assessment of plants in the all selected areas of wetland. Following formulas were being applied for calculation.

\section{Density}

Density is an expression number of the individual per unit area. Density is calculated by the equation.

$$
\begin{aligned}
& \text { Density } \\
& =\frac{\text { Total number of individual of particular species }}{\text { Total number of quadrates studied } \times \text { Area of quadrat(ha) }}
\end{aligned}
$$

\section{Frequency}

Frequency refers to the degree of dispersion of individual species in an area and usually expressed in term of percentage cover and it can be calculated by equation.

Frequency
$=\frac{\text { Number of quadrates in which species occurred }}{\text { Total number of quadrates studied }}$
$\times 100$

\section{Abundance}

Abundance refers the number of individual of different species in community unit per area. By quadrates methods, sampling is made random at several places and the number of individual of each species was summed up for all quadrates divided by total number of quadrates in which the species occurred. It can be represented by an equation.

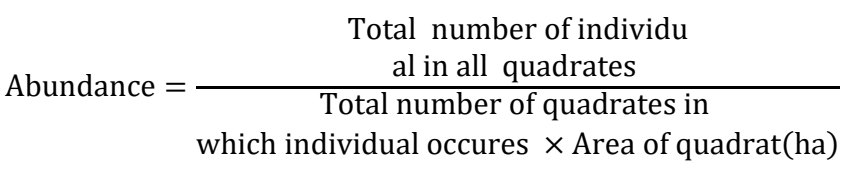

\section{RESULTS AND DISCUSSION}

\section{Qualitative analysis}

During the present study, a total of 74 species belonging to 39 families and 63 genera of flowering plants and 2 non-flowering i.e. Chara sp. (Algae) as well as Marsilea quadrifolia L. (pteridophyte) have been recorded from the in and around the Pariej wetland. Dicots represented by 48 species belongs to 41 genera and 29 families while Monocots represented by 26 species belongs to 20 genera and 9 families (Graph 1). Graph 2 showed habit wise analysis of plants i.e., tree, shrubs, climber, herbs, etc. Moreover, plant checklist was prepared based on the visual observation in the quadrats as well transects (Table 6). Graph 1 representing percentage of Dicot, Monocot, Algae, Pteridophyte and graph 2 representing habit percentage.

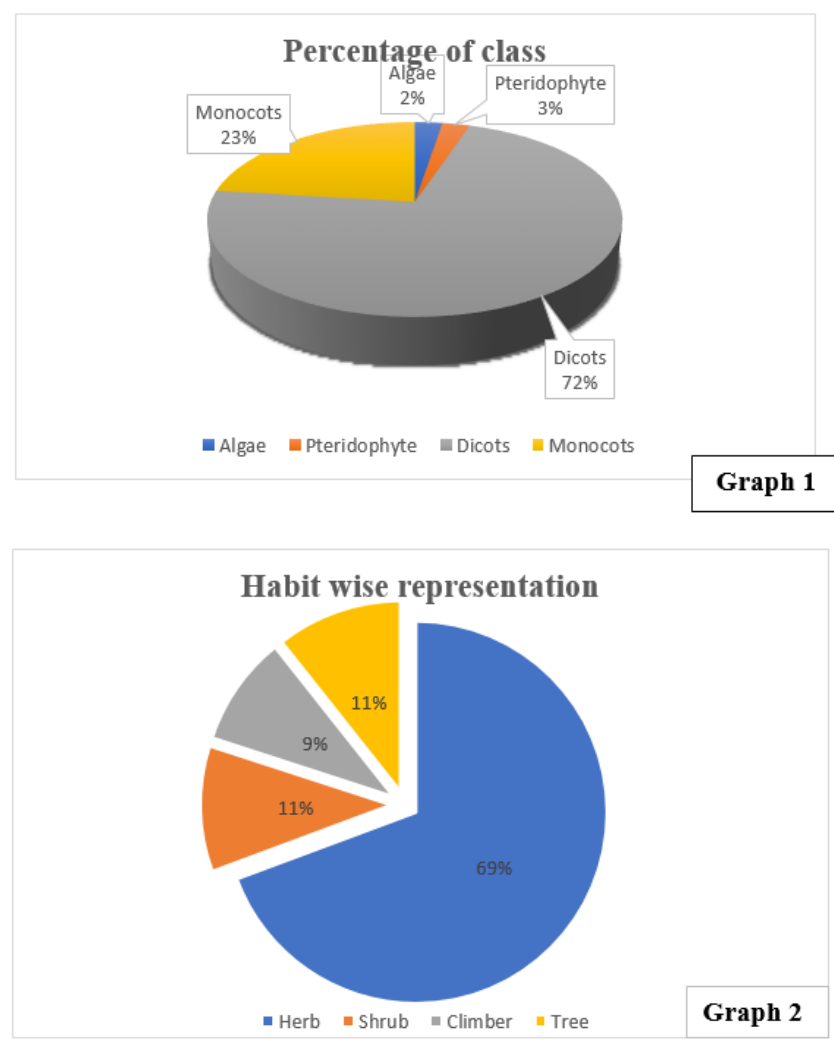

Out of 49 families, 48 genera are represented by single species of each genus. Convolvulaceae is largest families among the dicot while Poaceae and 
Cyperaceae are largest among the monocots which are poorly represented. A total of 74 species of flowering plants, 51 species are herbs, 8 species are shrubs, 7 species are climbers and 8 species are trees and 1 non-flowering plant Marsilea (pteridophyte). This study show that herbaceous plants are dominating in the wetland and its surrounding areas.

\section{Most representative family and genera in Pariej Wetland}

Most representative family, genera and species of Pariej are Asteraceae (7 species) followed by Poaceae (7 species), Cyperaceae (6 species), Convolvulaceae (5 species), Hydrocharitaceae (4 species) etc. as given in graph 3.

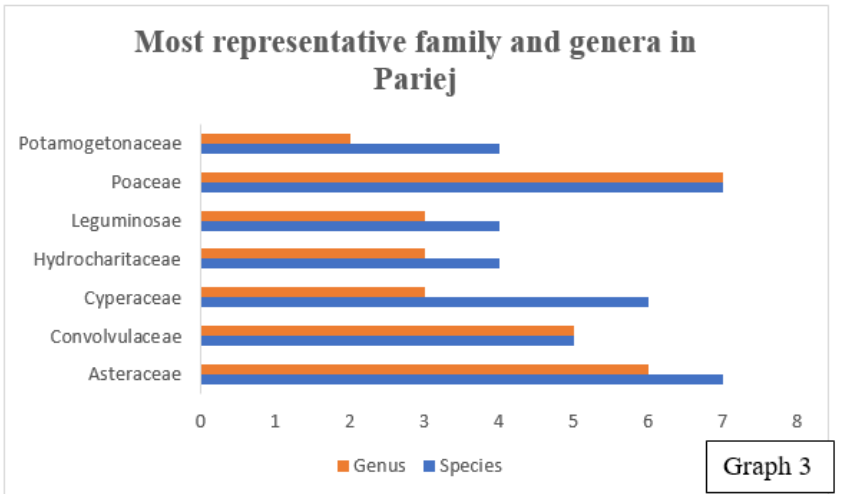

\section{Aquatic macrophytes}

The macrophytes are classified into submerged, free floating, rooted floating and emergent vegetation. Total 32 species recorded under this study belonged to 18 families. Majority of the species are recorded from emergent (13 species) vegetation followed by submerged (10 species), Rooted floating (7 species) and Free floating (2 species) Vegetation, etc. (graph 3)

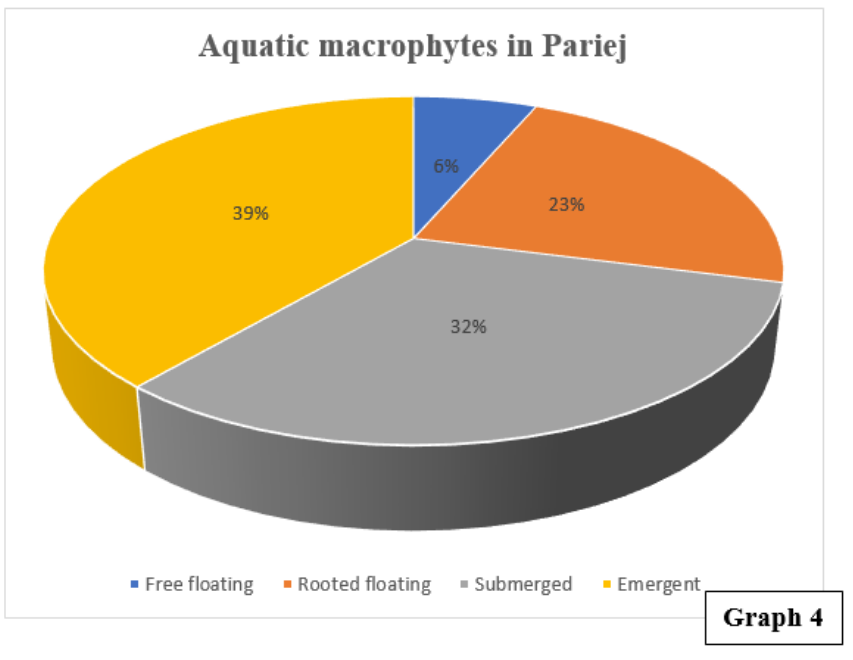

Majority of the species are recorded from Cyperaceae family (6 species) followed by Convolvulaceae (4 species), Hydrocharitaceae (4 species), and Potamogetonaceae (4 species). Other Family wise Distribution of aquatic macrophytes in Pariej wetland. (graph 4)

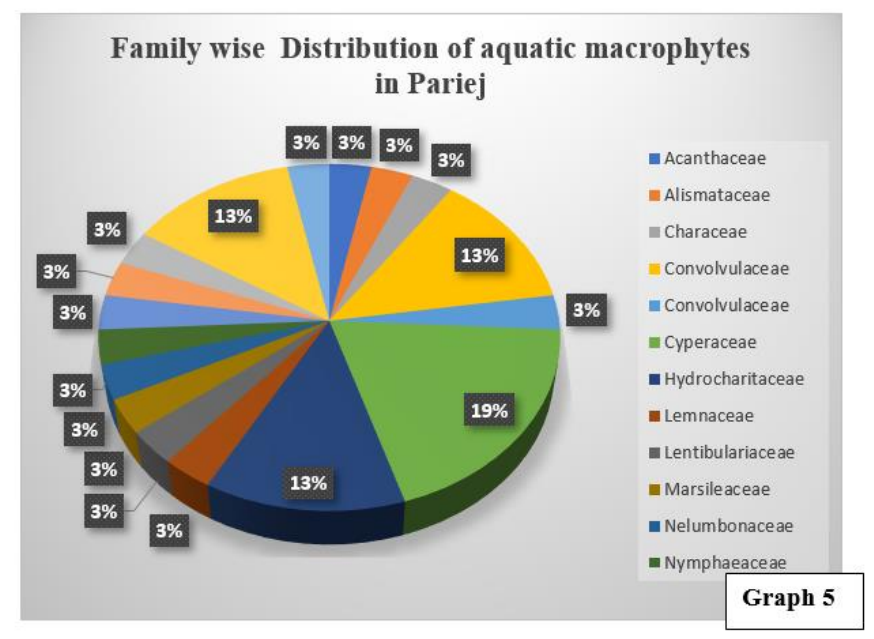

During fieldwork at Pariej wetland 32 species of aquatic macropytes were identified and listed based on the visual observation in the quadrats as well transects by using Cook (1996) and Shah (1978). The given table show list of aquatic macrophytes with their indicator statuses, habit, family, class etc.(table1)

Table 1 : List of recorded aquatic macrophytes and their indicator status.

\begin{tabular}{|l|l|c|c|c|c|c|}
\hline $\begin{array}{l}\text { Sr. } \\
\text { No. }\end{array}$ & Botanical Name & Family & Status & Habit & $\begin{array}{c}\text { Indicator } \\
\text { status }\end{array}$ & Class \\
\hline 1 & Ammannia baccifera L. & Lythraceae & Emergent & Herb & FAC & Dicot \\
\hline 2 & Coix lacryma-jobi L. & Poaceae & Emergent & Herb & FACW & Monocot \\
\hline
\end{tabular}


Jaivin Patel et al Int J Sci Res Sci \& Technol. March-April-2021, 8 (2) : 316-325

\begin{tabular}{|c|c|c|c|c|c|c|}
\hline 3 & Cyperus difformis $\mathrm{L}$. & Cyperaceae & Emergent & Herb & FACW & Monocot \\
\hline 4 & Cyperus iria L & Cyperaceae & Emergent & Herb & FACW & Monocot \\
\hline 5 & Cyperus rotundus $\mathrm{L}$. & Cyperaceae & Emergent & Herb & FACW & Monocot \\
\hline 6 & Cyperus bulbosus Vahl & Cyperaceae & Emergent & Herb & FACW & Monocot \\
\hline 7 & $\begin{array}{l}\text { Eichhornia crassipes (Mart.) } \\
\text { Solms }\end{array}$ & Pontederiaceae & $\begin{array}{c}\text { Free } \\
\text { Floating }\end{array}$ & Herb & OBL & Monocot \\
\hline 8 & Fimbristylis aestivalis Vahl & Cyperaceae & Emergent & Herb & FACW & Monocot \\
\hline 9 & $\begin{array}{l}\text { Hydrilla verticillata (L.f.) } \\
\text { Royle }\end{array}$ & Hydrocharitaceae & Submerged & Herb & OBL & Monocot \\
\hline 10 & $\begin{array}{l}\text { Hygrophila auriculata } \\
\text { (Schum.) Heine }\end{array}$ & Acanthaceae & Emergent & Herb & FACW & Dicot \\
\hline 11 & Ipomoea aquatica Forssk. & Convolvulaceae & $\begin{array}{l}\text { Rooted } \\
\text { Floating }\end{array}$ & Climber & FACW & Dicot \\
\hline 12 & Ipomoea carnea Jacq. & Convolvulaceae & Emergent & Climber & FACW & Dicot \\
\hline 13 & $\begin{array}{l}\text { Ipomoea marginata (Desr.) } \\
\text { Verdc. }\end{array}$ & Convolvulaceae & $\begin{array}{l}\text { Rooted } \\
\text { Floating }\end{array}$ & Climber & FACW & Dicot \\
\hline 14 & Ipomoea triloba L. & Convolvulaceae & $\begin{array}{l}\text { Rooted } \\
\text { Floating }\end{array}$ & Climber & FACW & Dicot \\
\hline 15 & Lemna minor $\mathrm{L}$. & Lemnaceae & $\begin{array}{c}\text { Free } \\
\text { Floating }\end{array}$ & Herb & OBL & Monocot \\
\hline 16 & $\begin{array}{l}\text { Limnophyton obtusifolium } \\
\text { (L.) Miq. }\end{array}$ & Alismataceae & Emergent & Herb & FACW & Monocot \\
\hline 17 & $\begin{array}{l}\text { Ludwigia adscendens (L.) } \\
\text { Hara }\end{array}$ & Onagraceae & Emergent & Herb & FACW & Dicot \\
\hline 18 & Najas marina L. & Hydrocharitaceae & Submerged & Herb & OBL & Monocot \\
\hline 19 & Najas minor All. & Hydrocharitaceae & Submerged & Herb & OBL & Monocot \\
\hline 20 & Nelumbo nucifera Gaertn. & Nelumbonaceae & $\begin{array}{c}\text { Rooted } \\
\text { Floating }\end{array}$ & Herb & OBL & Dicot \\
\hline 21 & Nymphaea nouchali Burm.f. & Nymphaeaceae & $\begin{array}{l}\text { Rooted } \\
\text { Floating }\end{array}$ & Herb & OBL & Dicot \\
\hline 22 & $\begin{array}{l}\text { Persicaria glabra (Willd.) } \\
\text { M.Gómez }\end{array}$ & Polygonaceae & Emergent & Herb & FACW & Dicot \\
\hline 23 & Potamogeton crispus L. & Potamogetonaceae & Submerged & Herb & OBL & Monocot \\
\hline 24 & Potamogeton nodosus Poir. & Potamogetonaceae & Submerged & Herb & OBL & Monocot \\
\hline 25 & Potamogeton perfoliatus L. & Potamogetonaceae & Submerged & Herb & OBL & Monocot \\
\hline 26 & Scirpus littoralis Schrad. & Cyperaceae & Emergent & Herb & FACW & Monocot \\
\hline 27 & $\begin{array}{l}\text { Stuckenia pectinata (L.) } \\
\text { Börner }\end{array}$ & Potamogetonaceae & Submerged & Herb & OBL & Monocot \\
\hline 28 & Typha domingensis Pers. & Typhaceae & Emergent & Herb & FACW & Monocot \\
\hline 29 & Utricularia inflexa Forssk. & Lentibulariaceae & Submerged & Herb & OBL & Dicot \\
\hline 30 & Vallisneria spiralis $\mathrm{L}$. & Hydrocharitaceae & Submerged & Herb & OBL & Monocot \\
\hline
\end{tabular}


Jaivin Patel et al Int J Sci Res Sci \& Technol. March-April-2021, 8 (2) : 316-325

\begin{tabular}{|l|l|c|c|c|c|c|}
31 & Chara sp. & Characeae & Submerged & - & OBL & Algae \\
\hline 32 & Marsilea quadrifolia L. & Marsileaceae & $\begin{array}{c}\text { Rooted } \\
\text { Floating }\end{array}$ & Herb & OBL & Pteridophyte \\
\hline
\end{tabular}

* Obligate Wetland Plants (OBL), Facultative Wetland Plants (FACW), Facultative Plants(FAC), Facultative Upland Plants (FACU), Obligate Upland Plants (UPL).

\section{Wetland indicator status}

The National List of Plant Species that Occur in Wetlands is a list of wetland plants and their assigned indicator statuses. The five indicator statuses are: Obligate Wetland Plants (OBL), Facultative Wetland Plants (FACW), Facultative Plants (FAC), Facultative Upland Plants (FACU), Obligate Upland Plants (UPL). Based on these indicator statuses total of 76 species of plants were categories and represented. Out of these, 38 species belong to Obligate Upland Plants, 16 Facultative Wetland Plants, 15 Obligate Wetland Plants, 6 Facultative Upland Plants and 1naturalized, 1 Facultative Plants. (graph 5)

\section{Quantitative analysis}

\section{Percent Cover}

32 species of macrophytes were recorded in the Pariej wetland. Out of these, 11species of macrophytes were recorded in the quadrats laid along with transects. The study reveals that the maximum Percent Cover was found of Hydrilla verticillata (L.f.) Royle (45.15\%) follow by Eichhornia crassipes (Mart.) Solms (41.42\%), Stuckenia pectinata (L.) Börner (38.33\%), Najas minor All (33.75\%) in winter season etc. (Table 2).

Table 2 : Percent cover of macrophytes

\begin{tabular}{|r|l|r|r|r|r|}
\hline \multirow{2}{*}{ SN Species Name } & \multicolumn{1}{|c|}{$\begin{array}{l}\text { Common } \\
\text { name }\end{array}$} & \multicolumn{3}{c|}{ \% Cover } \\
\cline { 3 - 6 } & & & Summer & Monsoon & Winter \\
\cline { 3 - 6 } & & - & 10 & 0 & 10 \\
\hline 1 & Chara sp. & - & 20 & 20 & 41.42 \\
\hline 2 & Eichhornia crassipes (Mart.) Solms & - & 44.83 & 26 & 45.15 \\
\hline 3 & Hydrilla verticillata (L.f.) Royle & - & 23.33 & 10 & 25 \\
\hline 4 & Lemna minor L. & & 15 & 10 & 10 \\
\hline 5 & Marsilea quadrifolia L. & & 21.81 & 23.63 & 26.66 \\
\hline 6 & Najas marina L. & & 30.43 & 26.92 & 33.75 \\
\hline 7 & Najas minor All. & - & 26.47 & 24.7 & 28 \\
\hline 8 & Nymphaea nouchali Burm.f. & - & 23.33 & 10 & 38.33 \\
\hline 9 & Potamogeton crispus L. & - & 36.66 & 20 & 30 \\
\hline 10 & Stuckenia pectinata (L.) Börner & & 22.85 & 20 & 28.57 \\
\hline 11 & Vallisneria spiralis L. & & & &
\end{tabular}




\section{Frequency}

An analysis of the study showed that the maximum frequency was found of Hydrilla verticillata (L.f.) Royle (94.29\%) in winter follow by Najas minor All (74.29\%) in monsoon, Potamogeton crispus L. (51.43\%) in winter, Najas marina L. (34.29\%) in winter season etc. (Table 3).

Table 3 : Frequency of macrophytes

\begin{tabular}{|c|c|c|c|c|c|}
\hline \multirow[b]{2}{*}{ SN } & \multirow[b]{2}{*}{ Species Name } & \multirow[t]{2}{*}{$\begin{array}{l}\text { Common } \\
\text { name }\end{array}$} & \multicolumn{3}{|c|}{ Frequency \% } \\
\hline & & & Summer & Monsoon & Winter \\
\hline 1 & Chara sp. & - & 2.86 & 0.00 & 2.86 \\
\hline 2 & Eichhornia crassipes (Mart.) Solms & - & 22.86 & 22.86 & 20.00 \\
\hline 3 & Hydrilla verticillata (L.f.) Royle & - & 88.57 & 85.71 & 94.29 \\
\hline 4 & Lemna minor L. & - & 8.57 & 2.86 & 5.71 \\
\hline 5 & Marsilea quadrifolia $\mathrm{L}$. & & 5.71 & 2.86 & 2.86 \\
\hline 6 & Najas marina $\mathrm{L}$. & & 31.43 & 31.43 & 34.29 \\
\hline 7 & Najas minor All. & & 65.71 & 74.29 & 68.57 \\
\hline 8 & Nymphaea nouchali Burm.f. & Poynu & 20.00 & 17.14 & 20.00 \\
\hline 9 & Potamogeton crispus L. & - & 48.57 & 48.57 & 51.43 \\
\hline 10 & Stuckenia pectinata (L.) Börner & - & 8.57 & 2.86 & 17.14 \\
\hline 11 & Vallisneria spiralis L. & - & 8.57 & 11.43 & 11.43 \\
\hline
\end{tabular}

\section{Density}

The study reveals that the maximum density was found of Typha domingensis Pers., $(9.80 \mathrm{Indi} / \mathrm{m})$ in winter follow by Polygonum plebeium R.Br. (3.27 indi/m) in winter, Eclipta prostrata (L.) L. (2.07indi/m) in summer, Ipomoea carnea Jace. (2.0 Indi/m) in summer season etc. (Table 4)

\section{Frequency}

In pariej wetland, the maximum frequency was found of Typha domingensis Pers. (93.33\%) in monsoon, Polygonum plebeium R.Br. (46.67 \%) in monsoon, Eclipta prostrata (L.) L. (33.33\%) in winter, Ipomoea carnea Jace. (33.33) in winter etc. (Table 4)

\section{Abundance}

An abundance of different species in the present study were Typha domingensis Pers.(12.25indi $/ \mathrm{m})$ in winter followed by Polygonum plebeium R.Br. (8.16 indi $/ \mathrm{m})$ in winter, Ammannia baccifera L.(6.00 indi $/ \mathrm{m})$ in winter, Ipomoea carnea Jace. (5.2 indi/m) in winter season etc. (Table 4) 


\section{Percentage composition}

The percentage compositions of dominant species were Typha domingensis Pers. (53.26\%) in winter followed by Polygonum plebeium R.Br. (17.75 \%) in winter, Ipomoea carnea Jace. (9.42\%) in winter, Eclipta prostrata (L.) L. (6.90\%) in monsoon season etc. (Table 4)

Table 4 : Density, frequency, abundance and Percentage composition of Upland plant in Pariej wetland

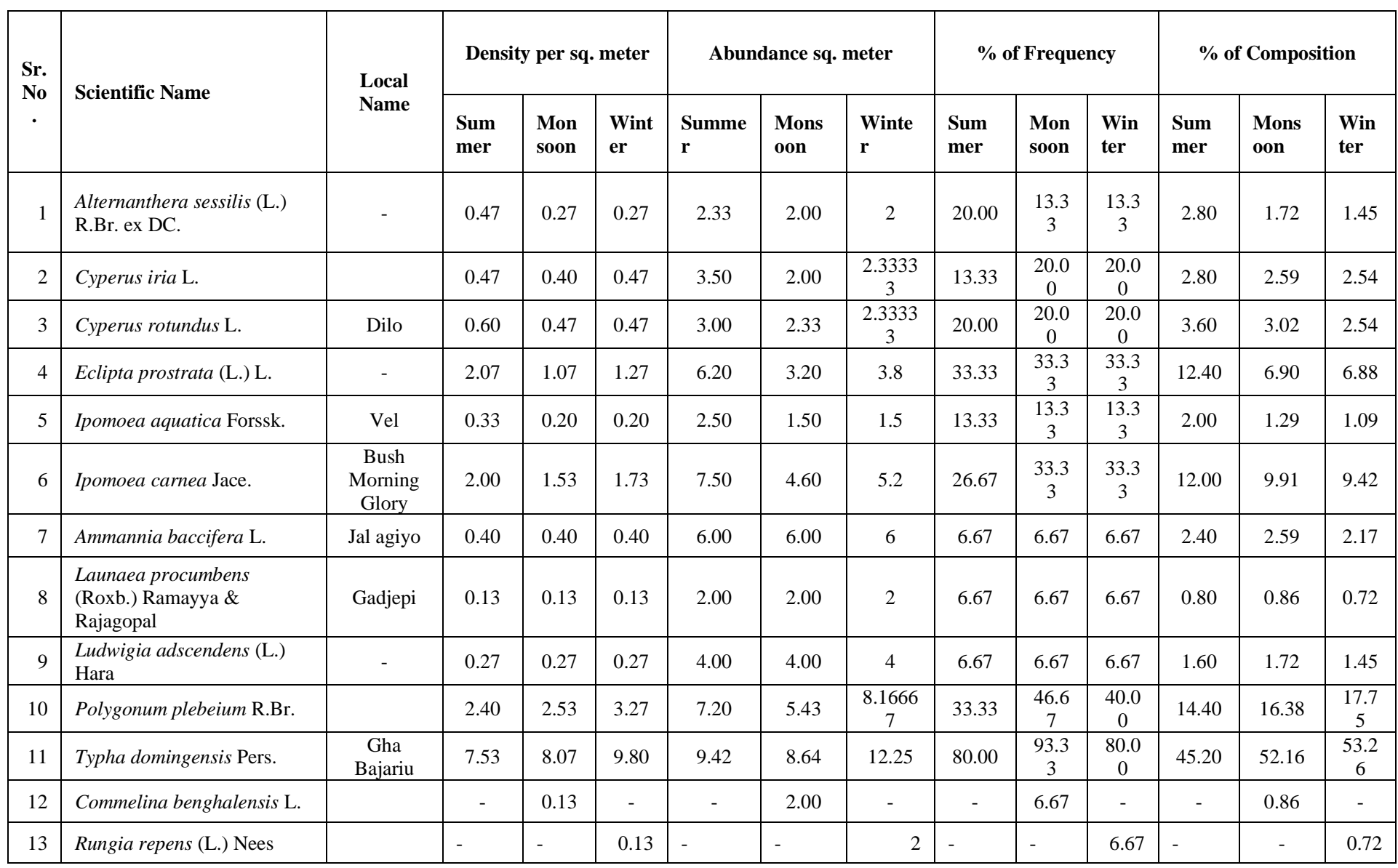

\section{IV.CONCLUSION}

Wetlands are most productive ecosystem. Vegetation plays important role in wetland ecosystem. It acts as primary producer who makes food. Vegetation takes part vital chain like energy flow, food web, carbon cycle, Nitrogen cycle, phosphate cycle. It acts as basic trophic level for biomass production, which further passes to another trophic levels.

In the present study, a total of 74 species belonging to 39 families and 63 genera of flowering plants and 2 non-flowering i.e. Chara sp. (Algae) as well as
Marsilea quadrifolia L. (pteridophyte) have been recorded in and around the Pariej wetland. Dicots represented by 48 species belongs to 41 genera and 29 families while Monocots represented by 26 species belongs to 20 genera and 9 families.

The macrophytes are classified into submerged, free floating, rooted floating and emergent vegetation. A total 32 aquatic macrophytes species recorded under this study belonged to 18 families. Majority of the species are recorded from emergent (13 species) vegetation followed by submerged (10 species), 
Rooted floating (7 species) and Free floating (2 species) Vegetation.

Based on the National List of wetland plants and their assigned indicator statuses a total of 76 species of plants were categories. Out of these, 38 species belong to Obligate Upland Plants, 16 Facultative Wetland Plants, 15 Obligate Wetland Plants, 6 Facultative Upland Plants and 1 naturalized, 1 Facultative Plants.

Thus wetlands require collaborated research involving natural, social and inter disciplinary study aimed at understanding the various components such as monitoring of water quality, socio economic dependency, bio diversity and other activities as an indispensable tool for formulating long term conservation strategies.

\section{REFERENCES}

[1]. Adam, E., Mutanga, O., \& Rugege, D. (2010). Multispectral and hyperspectral remote sensing for identification and mapping of wetland vegetation: a review. Wetlands Ecology and Management, 18(3), 281-296.

[2]. Anderson, G. L., Hanson, J. D., \& Haas, R. H. (1993). Evaluating Landsat Thematic Mapper derived vegetation indices for estimating aboveground biomass on semiarid rangelands. Remote sensing of Environment, 45(2), 165175.

[3]. Anderson, M. J., Crist, T. O., Chase, J. M., Vellend, M., Inouye, B. D., Freestone, A. L., \& Harrison, S. P. (2011). Navigating the multiple meanings of $\beta$ diversity: a roadmap for the practicing ecologist. Ecology letters, 14(1), 1928.

[4]. Burlakova, L. E., Karatayev, A. Y., Padilla, D. K., Cartwright, L. D., \& Hollas, D. N. (2009). Wetland restoration and invasive species: apple snail (Pomacea insularum) feeding on native and invasive aquatic plants. Restoration Ecology, 17(3), 433-440.
[5]. Callaway, J. C., Sullivan, G., \& Zedler, J. B. (2003). Species-rich plantings increase biomass and nitrogen accumulation in a wetland restoration experiment. Ecological Applications, 13(6), 1626-1639.

[6]. Carlsson, F., Frykblom, P., \& Liljenstolpe, C. (2003). Valuing wetland attributes: an application of choice experiments. Ecological economics, 47(1), 95-103.

[7]. Chandra, P., \& Kulshreshtha, K. (2004). Chromium accumulation and toxicity in aquatic vascular plants. The Botanical Review, 70(3), 313-327.

[8]. Chatrath, K. J. S. (1992). Wetlands of IndiaMajor threats faced by wetlands of India and their conservative measures. Ashish Publication House, New Delhi, 22-32.

[9]. Cook, C. D. (1996). Aquatic and Wetland Plants of India: A reference book and identification manual for the vascular plants found in permanent or seasonal fresh water in the subcontinent of India south of the Himalayas (Vol. 198548214). Oxford: Oxford University Press 385p.

[10]. Dabgar, P. J. (2012). A contribution to the flora of Wadhvana wetland, Dabhoi Taluka (Gujarat) India. Bioscience Discovery, 3(2), 218-221.

[11]. Dahal, B. R., \& Buckton, S. (2007). Using pardcipatory socio-economic wetland valuadon to address wetland management issues at Koshi Tappu, Nepal. In to the Internadonal Conference on Managing Wetlands for Sustainable Development: InnovaXve Research and Lessons Learned, E ecXve Partnerships, and the Need for Co-Management. Thailand.

[12]. Darajeh, N., Idris, A., Masoumi, H. R. F., Nourani, A., Truong, P., \& Sairi, N. A. (2016). Modeling BOD and COD removal from Palm Oil Mill Secondary Effluent in floating wetland by Chrysopogon zizanioides (L.) using response surface methodology. Journal of environmental management, 181, 343-352. 
[13]. Shah, G. L. (1978). Flora of Gujarat state. vol. I \& II. Sardar Patel University, Vallabh Vidyanagar.

[14]. Tatu, K. S., Anderson, J. T., Hindman, L. J., \& Seidel, G. (2007). Mute swans' impact on submerged aquatic vegetation in Chesapeake Bay. Journal of Wildlife Management, 71(5), 1431-1439.

[15]. Turner, R. K., Van Den Bergh, J. C., Söderqvist, T., Barendregt, A., Van Der Straaten, J., Maltby, E., \& Van Ierland, E. C. (2000). Ecologicaleconomic analysis of wetlands: scientific integration for management and policy. Ecological economics, 35(1), 7-23.

\section{Cite this article as :}

Jaivin Patel, Dr. Rupesh Maurya, Dr. Hitesh Solanki, Dr. Bharat Maitreya, "Vegetation Assessment of Inland Wetland of Central Gujarat ( Pariej Irrigation Reservoirs )", International Journal of Scientific Research in Science and Technology (IJSRST), Online ISSN : 2395-602X, Print ISSN : 2395-6011, Volume 8 Issue 2, pp. 316-325, March-April 2021. Available at doi : https://doi.org/10.32628/IJSRST218243

Journal URL : https://ijsrst.com/IJSRST218243 